\title{
Special issue on contamination, remediation and health for pollutants in natural aquatic, soil, sediments and atmospheric environments
}

\author{
Kitae Baek • Daniel S. Alessi • Yu Bon Man • Eilhann E. Kwon
}

Published online: 24 July 2021

(C) The Author(s), under exclusive licence to Springer Nature B.V. 2021

The International Environmental Engineering Conference (IEEC 2019) and Annual Meeting of the Korean Society of Environmental Engineers met jointly with the 4th International Conference on Biological Waste as Resources (BWR 2019) at the BEXCO on December 10-13, 2019 in Busan, Republic of Korea. IEEC 2019 aimed to offer a comprehensive platform for researchers, scientists, engineers and policy makers working in the diverse fields of environmental research to exchange their valuable knowledge.

K. Baek ( $\square)$

Department of Environment and Energy (BK21 FOUR), Jeonbuk National University, Jeonju,

Jeollabukdo 54896, Republic of Korea

K. Baek

Soil Environment Research Center, Jeonbuk National University, Jeonju, Jeollabukdo 54896, Republic of Korea

D. S. Alessi

Department of Earth and Atmospheric Sciences, University of Alberta, Edmonton, AB T6G 2E3, Canada

\section{Y. B. Man}

Consortium On Health, Environment, Education and Research (CHEER), Department of Science and Environmental Studies, The Education University of Hong Kong, Tai Po, Hong Kong, People's Republic of China

\section{E. E. Kwon}

Department of Environment and Energy, Sejong University, Seoul 05006, Republic of Korea
BWR 2019 also deliberated the state-of-the-art technologies, advanced management strategies and political issues pertaining to treatment, recycling and recovery processes of organic wastes.

More than 1,400 experts and scholars from 23 countries attended the joint conferences. The conferences set up nine special symposia covering a broad range of environmental topics (such as climate technology, renewable and sustainable energy, wastewater technology, energy and resource recovery, wastes treatment and management and soil and groundwater remediation). The joint conferences aimed to catalyze the full integration of all research disciplines, particularly focusing on resources recovery and management.

This special issue collected five research articles and onr review paper. Park et al. (2021) reviewed extraction technologies to remediate cesium-contaminated soils and suggested enhanced desorption strategies to increase the removal efficiency of cesium. Basak et al. (2021) determined the fates of potassium and micronutrients from a quarry rock mineral powder. Moon et al.(2021) proposed an iron-based soilwashing technique to remediate lead-, copper- and zinc-contaminated paddy soil. Lyonga et al. (2021) reported a new biochar-based adsorbent derived from food waste for removal of As(III). Kim and Ko (2021) reported on the leaching potential of dissolved organic matters in sediment samples collected adjacent to roads. Finally, Mungruaiklang and Iwai (2021) offered 
a heuristic vermiwash method to enhance the vermification of swine farm wastewater.

We would like to express our sincere gratitude to all fo the contributors, reviewers, and the staff of Environmental Geochemistry and Health and Springer Nature. Lastly, we appreciate Professor Ming Hung Wong, the Editor-in-Chief of the Environmental Geochemistry and Health, for his endless support in organizing this special issue.

\section{References}

Basak, B. B., Sarkar, B., \& Naidu, R. (2021). Environmentally safe release of plant available potassium and micronutrients from organically amended rock mineral powder. Environmental Geochemistry and Health. https://doi.org/10. 1007/s10653-020-00677-1

Kim, D.-G., \& Ko, S.-O. (2021). Road-deposited sediments mediating the transfer of anthropogenic organic matter to stormwater runoff. Environmental Geochemistry and Health. https://doi.org/10.1007/s10653-020-00703-2
Lyonga, F. N., Hong, S.-H., Cho, E.-J., Kang, J.-K., Lee, C.-G., \& Park, S.-J. (2021). As(III) adsorption onto Fe-impregnated food waste biochar: Experimental investigation, modeling, and optimization using response surface methodology. Environmental Geochemistry and Health. https://doi.org/10.1007/s10653-020-00739-4

Moon, D. H., Chang, Y.-Y., Lee, M., Koutsospyros, A., Koh, I.H., Ji, W. H., \& Park, J.-H. (2021). Assessment of soil washing for heavy metal contaminated paddy soil using $\mathrm{FeCl} 3$ washing solutions. Environmental Geochemistry and Health. https://doi.org/10.1007/s10653-021-00815-3

Mungruaiklang, N., \& Iwai, C. B. (2021). Using vermiwash to enhance performance of small-scale vermifiltration for swine farm wastewater. Environmental Geochemistry and Health. https://doi.org/10.1007/s10653-021-00816-2

Park, S.-M., Kim, J.-G., Kim, H.-B., Kim, Y.-H., \& Baek, K. (2021). Desorption technologies for remediation of cesium-contaminated soils: A short review. Environmental Geochemistry and Health. https://doi.org/10.1007/s10653020-00667-3

Publisher's Note Springer Nature remains neutral with regard to jurisdictional claims in published maps and institutional affiliations. 